\title{
Experimental model of severe acute pancreatitis in rabbits ${ }^{1}$
}

\author{
Modelo experimental de pancreatite aguda grave em coelhos
}

\author{
Alberto Goldenberg², Ana Celia Diniz Cabral Barbosa Romeo ${ }^{3}$, Márcia Bento Moreira ${ }^{4}$, Franz Robert Apodaca ${ }^{5}$, \\ Marcelo Moura Linhares ${ }^{6}$, Jacques Matone ${ }^{7}$ \\ 1. Research performed at Division of Operative Technique and Experimental Surgery, Department of Surgery, Federal University of Sao Paulo \\ (UNIFESP) and the Veterinary Hospital of Bandeirantes University (UNIBAN), São Paulo, Brazil. \\ 2. PhD, Associate Professor, Department of Surgery, Division Gastrointestinal Surgery, UNIFESP, São Paulo, Brazil. \\ 3. Master, UNIFESP, São Paulo, Brazil. \\ 4. PhD, Associate Professor, Department of Surgery, UNIBAN and Cruzeiro do Sul University (UNICSUL), São Paulo, Brazil. \\ 5. PhD, Assistant Professor, Department of Surgery, Division Gastrointestinal Surgery, UNIFESP, São Paulo, Brazil. \\ 6. PhD, Department of Surgery, Division Gastrointestinal Surgery, UNIFESP, São Paulo, Brazil. \\ 7. Fellow PhD degree, UNIFESP, São Paulo, Brazil.
}

\section{ABSTRACT}

Purpose: To develop an experimental model of severe acute pancreatitis in rabbits through a pancreatic ductal injection of sodium taurocholate. Methods: Twenty-four albino rabbits of the New Zealand lineage were distributed into four groups of six animals (A, B, C and S). The rabbits of three experimental groups (A, B and C) were submitted to a laparatomy and received a pancreatic ductal injection of $1 \mathrm{ml} / \mathrm{kg}$ sodium taurocholate $5 \%$. Also, they were submitted to further laparatomies after $4 \mathrm{~h}, 8 \mathrm{~h}$ and $12 \mathrm{~h}$, respectively. The control group (S) was subdivided into two groups of three animals: in subgroup S1 only the pancreatic duct catheterization was performed whereas in subgroup S2 the pancreatic duct catheterization as well as an injection of $1 \mathrm{ml} / \mathrm{kg}$ physiologic solution $0.9 \%$ were carried out. After 12 hours, the rabbits were evaluated. In the re-intervention, blood was collected to determine the amylasemia and a pancreatectomy was carried out to investigate interstitial infiltration, steatonecrosis and necrosis of the organ, using an optical microscope. Results: There was an elevation of amylase in all groups thus proving the existence of acute pancreatitis. The size of the interlobular septum increased progressively with a greater variation between group S1 (0.13) and group $C(0.53)(p=0.035)$. While all the animals in group A exhibited focal cellular necrosis, it was more intense in the rabbits of group $B$ and culminated with a high proportion of severe pancreatic necrosis in group $C$ animals. The difference in the intensity of cellular necrosis showed statistic significance $(p=0.001)$. Conclusion: The proposed experimental model demonstrated its reproducibility and effectiveness in producing severe acute pancreatitis in rabbits. Key words: Pancreatitis, Acute Necrotizing. Animal Experimentation. Rabbits.

\section{RESUMO}

Objetivo: Desenvolver modelo experimental de pancreatite aguda grave em coelhos por meio da injeção de taurocolato de sódio no ducto pancreático. Métodos: Vinte e quatro coelhos albinos da linhagem Nova Zelândia foram distribuídos em quatro grupos de seis animais (A, B, C e S). Os coelhos dos três grupos experimentais (A, B e C) foram submetidos a laparotomia e injetou-se taurocolato de sódio a 5\%, 1ml/Kg no ducto pancreático. Realizou-se nova laparotomia, respectivamente, após $4 \mathrm{~h}$, $8 \mathrm{~h}$ e $12 \mathrm{~h}$. No grupo controle (S), subdividido em dois grupos de três animais, foi realizada no subgrupo S1 apenas cateterização do ducto pancreático e no subgrupo S2 cateterização do ducto pancreático e injeção de solução fisiológica $0,9 \%, 1 \mathrm{ml} / \mathrm{Kg}$. Estes animais foram reavaliados após 12 horas. Na reintervenção coletou-se sangue para determinação da amilasemia e realizou-se pancreatectomia para análise histológica do infiltrado intersticial, da esteatonecrose e da necrose do órgão. Resultados: Houve elevação da amilase em todos os grupos, demonstrando a presença da pancreatite aguda. O tamanho do septo interlobular aumentou progressivamente, observando-se maior diferença entre os grupos S1 $(0,13)$ e C $(0,53)(p=0,035)$. Todos os animais do grupo A apresentaram necrose celular focal que se tornou mais intensa nos coelhos do grupo B, culminando com o predomínio de necrose pancreática acentuada nos animais do grupo C. A diferença na intensidade da necrose celular apresentou significância estatística ( $p=0,001)$. Conclusão: O modelo experimental proposto se mostrou reprodutível e efetivo em provocar pancreatite aguda grave em coelhos. Descritores: Pancreatite Necrosante Aguda. Experimentação Animal. Coelhos. 


\section{Introduction}

Acute pancreatitis is a multi-etiology disease, with controversial physiopathology, no specific efficient treatment and unpredictable evolution. The disease is classified in two different phases ${ }^{1}$ : edematous (mild) and necrotizing (severe). This distinction is made according to clinical and laboratorial parameters, presence of multiple organ failure and the morphology of the pancreatic gland after endovenous contrast-enhanced computerized tomography ${ }^{2,3}$. Necrotizing acute pancreatitis represents $20 \%$ to $30 \%$ of patients, characterized by the severity of symptoms and high incidence of local and systemic complications 3 , with $2 \%$ to $20 \%$ mortality rate, despite the better understanding of the disease, as well as technological innovations in radiology, histopathology, bacteriology and intensive care ${ }^{3,5}$. Risk factors for the on-set of acute pancreatitis are numerous, including geographical concerns $^{4,5}$. Steinberg and Tenner ${ }^{5}$ published a study in 1994, listing 68 risk factors for acute pancreatitis, with 45\% of the cases due to cholelithiasis, followed by excessive alcohol ingestion 35\% and cryptogenic etiology 10\%.In Western countries, biliary gallstones are the most important etiology ${ }^{4}$. Although risk factors for acute pancreatitis are well known, the pathogenesis and treatment of the disease is still unclear and much of the knowledge until now is due to experimental studies ${ }^{6,7}$. New treatment modalities need to be tested before clinical use. In vitro models and cultured cells were not suitable to test efficacy and side effects of new drugs ${ }^{8}$. The experimental model for acute pancreatitis must be reproducible, with anatomical and pathological characteristics concerning pancreatitis similar to humans. The model should present low early mortality rate and allow subsequent intervention in the pancreas ${ }^{7}$. The aim of this study was to develop an experimental model of severe acute pancreatitis with intra-ductal injection of sodium taurocholate $5 \% \%^{7,9,10}$, in order to study systemic alterations due to this disease, as well as to develop new therapies to be used in clinical practice. We chose the rabbit to be the model, as it is bigger than the ratt,9,14-18, more blood tests could be performed in the research for new drug therapy. Moreover, few groups have used the rabbit for this purpose for acute pancreatitis ${ }^{10-13}$.

\section{Methods}

Twenty-four albino rabbits of the New Zealand (Oryctolagus cuniculus) lineage were distributed into four groups of six animals (A, B, C and S) aging 3 -4 months, females, weighing between 2.463,33g to 2.616,67g, manipulated according to rules and techniques of animal research from the COBEA (Brazilian Animal Experimentation Committee) The experimentations were performed in the Division of Operative Technique and Experimental Surgery (Federal University of Sao Paulo) and the Veterinary Hospital of Bandeirantes University
(UNIBAN). The research was approved by the Ethics in Research Committee of the Federal University of São Paulo (UNIFESP).

\section{Research design}

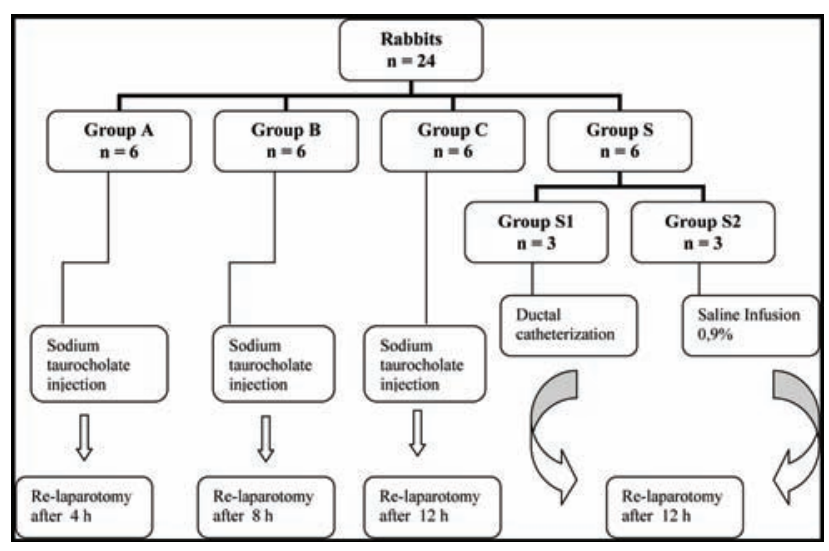

The animals were confined in cages under controlled feeding. Intramuscular injection of acepromazin (Acepram ${ }^{\circledR}$ 1\%), 10 mg/Kg was made ten minutes before each procedure. Anesthesia was carried out with xylazin (Anasedan ${ }^{\circledR}$ ), $10 \mathrm{mg} / \mathrm{Kg}$ and ketamin (Dopalen ${ }^{\circledR}$ ), 50 $\mathrm{mg} / \mathrm{Kg}$ intramuscular. Anesthesia was kept during the procedure by endovenous infusion of Xylazin and Ketamin half-dose, and spontaneous breathing with enriched oxygen mask. After antisepsis, rabbits underwent a 8,0 cm midline incision. The pancreatic duct was found after approximately $20 \mathrm{~cm}$ of the pylorus and, after opening the small bowel, a retrograde catheterization of the duct with a 24 gauge needle was done. Under manual pressure, a total of $1 \mathrm{~mL} /$ $\mathrm{Kg}$ of taurocholate infusion 5\% (Sigma Aldrich, Brazil, T9034) in saline was injected during one minute. The bowel was stitched and the abdominal wall was closed;

\section{Re-laparotomy}

The animals were again anesthetized. The abdominal was re-opened and macroscopic findings were recorded. A total pancreatectomy was performed and from the inferior cava vein was collected $15 \mathrm{~mL}$ of blood for examination. Animals underwent euthanasia by overdose of anesthesia medication.

\section{Laboratorial analysis}

Blood tests were performed in UNIFESP laboratory, separating the serum after clotting in 4.500 rotation/minute. Amylase was dosed under enzyme technique in ADVIA apparatus.

\section{Histological analysis}

The specimen were embedded in formaldehyd $10 \%$, stained with hematoxylin-eosin and evaluated in optic 
microscopy. The classification described in 1992 by Schmidt J et al. was used, taking into account interlobular septum, leukocyte infiltration, steatonecrosis and gland graduated necrosis, as follows:

\begin{tabular}{|l|l|l|l|}
\hline Cellular necrosis & Negative & Focal: & Difuse: \\
\hline & $\begin{array}{l}\text { Mild, } \\
\text { moderate } \\
\text { and severe }\end{array}$ & $\begin{array}{l}\text { Mild, } \\
\text { moderate } \\
\text { and severe }\end{array}$ \\
\hline Steatonecrosis & Negative & Positive & \\
\hline Intersticial infiltrate & Negative & $\begin{array}{l}\text { Mild, } \\
\text { moderate } \\
\text { and severe }\end{array}$ & \\
\hline
\end{tabular}

\section{Statistical analysis}

The groups were compared regarding categorical variables (steatonecrosis, interstitial infiltrate and pancreatic tissue necrosis) using the Fisher's exact test. To evaluate numeric variables (amylase and size of interlobular septum), ANOVA test was adopted, comparing the groups. In those where a significant difference was found, the multiple comparison test of Tukey identified the group with more important differences.

\section{Results}

Serum amylase was elevated, confirming the diagnosis of acute pancreatitis in all animals. Amylase values are showed for each group (Figure 1). Animals from group S1 had lower levels of amylase when compared to the other groups. After statistical analysis, there was no significant difference between the groups $(\mathrm{p}=0,316)$. The findings of the hystopathological analysis are the Tables 1, 2 and 3 showing the comparison of steatonecrosis, interstitial infiltrate and pancreatic tissue (Figure 2).

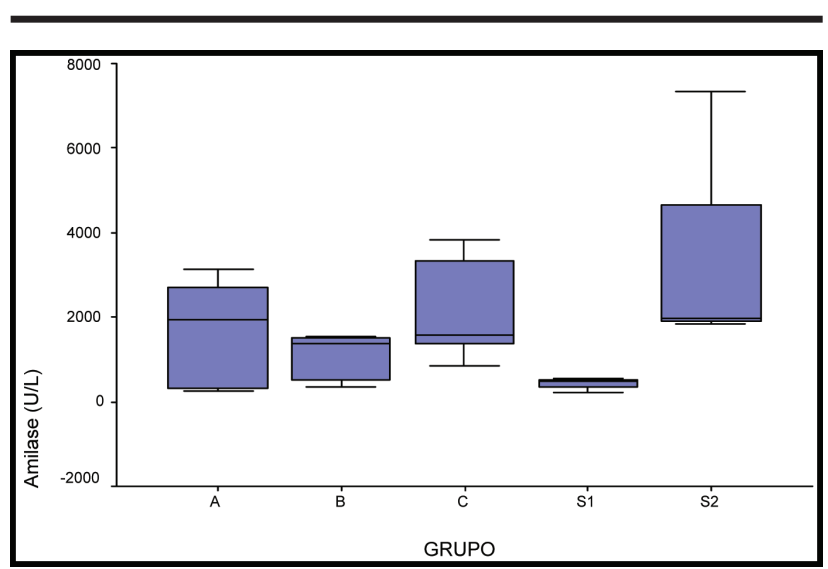

FIGURE 1 - Level of amylase in each group, confirming the presence of acute pancreatitis

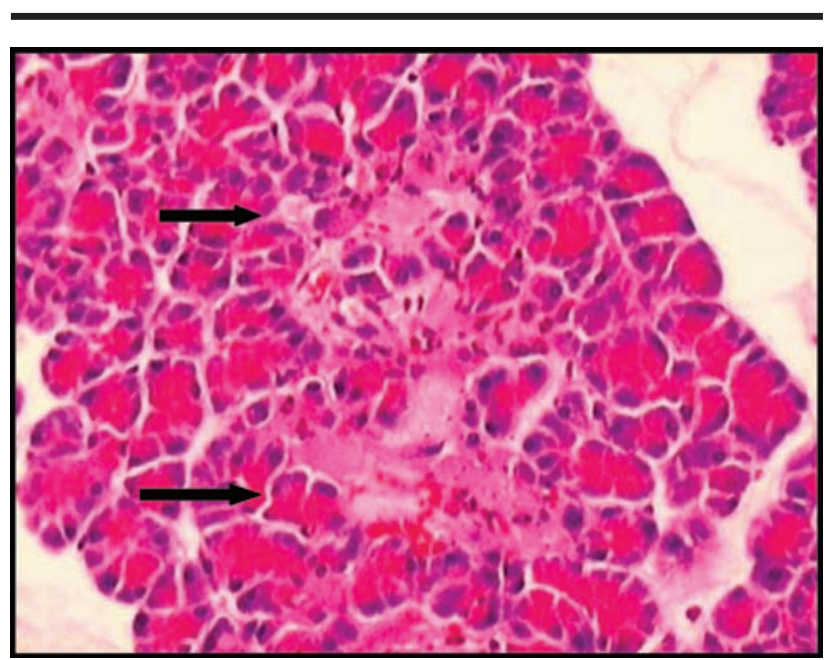

FIGURE 2 - Fotomicrograph. Steatonecrosis. Group C, rabbit 6 (100x)

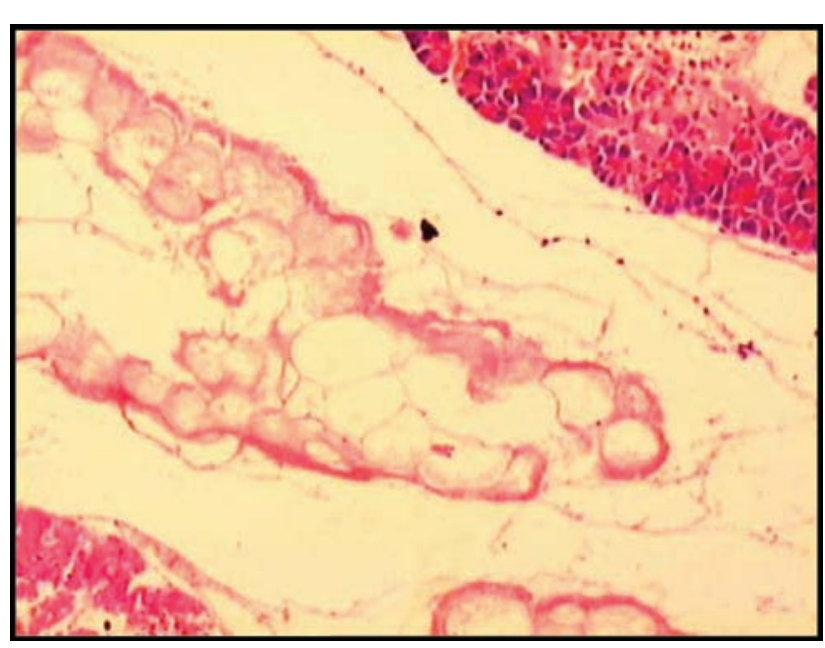

FIGURE 3 - Fotomicrograph. Focal, mild, necrotic pancreatic tissue (arrows). Group A, rabbit 6. $(100 x)$

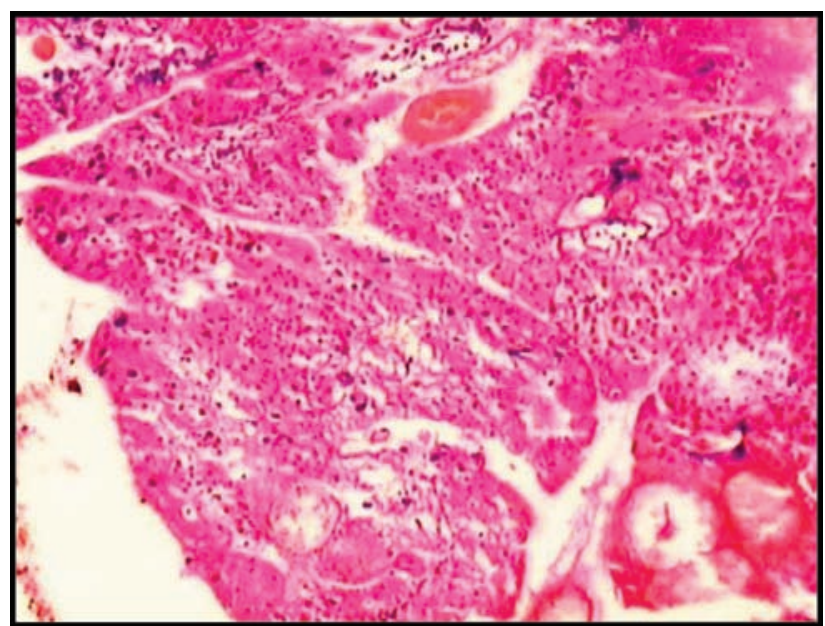

FIGURE 4 - Fotomicrograph. Severe, difuse, necrotic pancreatic tissue. Group C, rabbit 1. (100x) 
TABLE 1 - Steatonecrosis in each group

\begin{tabular}{lllllll}
\hline & \multicolumn{7}{c}{ Group } & \\
\cline { 2 - 6 } Steatonecroise1 & A & B & C & S1 & S2 & Total \\
\hline Absent & 6 & 4 & 2 & 3 & 2 & 17 \\
Present & 0 & 2 & 4 & 0 & 1 & 7 \\
\hline Total & 6 & 6 & 6 & 3 & 3 & 24 \\
\hline
\end{tabular}

TABLE 2 - Interstitial infiltrate in each group

\begin{tabular}{lcccccc}
\hline & \multicolumn{7}{c}{ Group } & \\
\cline { 2 - 6 } Interstitial inflitrate & $\boldsymbol{A}$ & $\boldsymbol{B}$ & $\boldsymbol{C}$ & $\boldsymbol{S 1}$ & $\boldsymbol{S 2}$ & Total \\
\hline Severe & 0 & 1 & 4 & 0 & 0 & 5 \\
Mild & 5 & 4 & 1 & 3 & 3 & 16 \\
Moderate & 1 & 1 & 1 & 0 & 0 & 3 \\
\hline Total & 6 & 6 & 6 & 3 & 3 & 24 \\
\hline
\end{tabular}

TABLE 3 - Pancreatic necrosis in each group

\begin{tabular}{lcccccc}
\hline & \multicolumn{7}{c}{ Group } & \\
\cline { 2 - 6 } Pancreatic Necrosis & $\boldsymbol{A}$ & $\boldsymbol{B}$ & $\boldsymbol{C}$ & $\boldsymbol{S 1}$ & $\boldsymbol{S 2}$ & Total \\
\hline Absent & 0 & 0 & 0 & 3 & 2 & 5 \\
Diffuse severe & 0 & 1 & 3 & 0 & 0 & 4 \\
Diffuse moderate & 0 & 1 & 0 & 0 & 0 & 1 \\
Focal severe & 0 & 1 & 1 & 0 & 0 & 2 \\
Focal mild & 6 & 1 & 0 & 0 & 0 & 7 \\
Focal moderate & 0 & 2 & 2 & 0 & 1 & 5 \\
\hline Total & 6 & 6 & 6 & 3 & 3 & 24 \\
\hline
\end{tabular}

TABLE 4 - Histopathological comparison of the groups

\begin{tabular}{lc}
\hline Variable & $\boldsymbol{p}$ \\
\hline Ssteatonecrosis & 0,089 \\
Interstitial infiltrate & 0,090 \\
Pancreatic necrosis & 0,001 \\
\hline
\end{tabular}

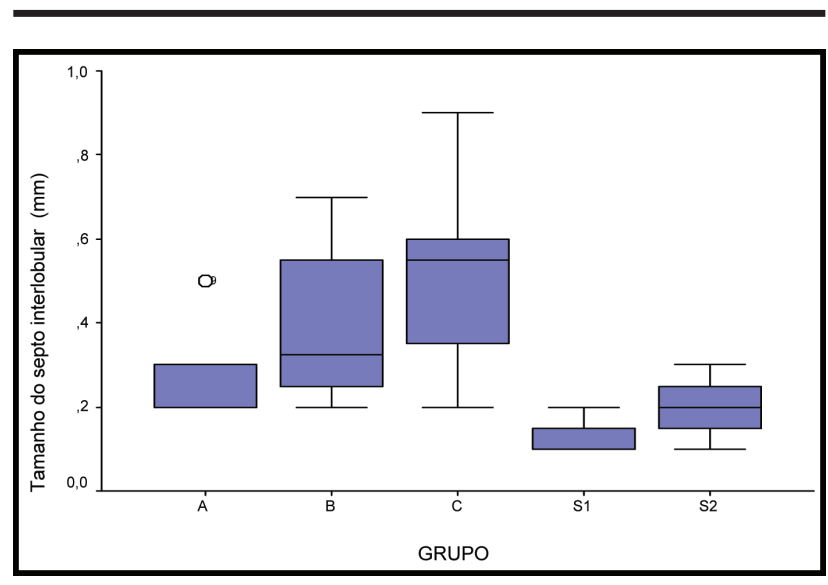

FIGURE 6 - Interlobular septum size in each group, showing cellular edema. The size of interlobular septum rose progressively

\section{Discussion}

The first time acute pancreatitis was experimentally induced was in 1856 when Bernard injected bile and olive oil in the pancreatic duct of dogs ${ }^{19}$. In 1862, Panum ${ }^{19}$ injected wax in pancreatic arteries, leading to pancreatitis due to focal ischemia; Moure ${ }^{19}$ reported that the excessive stimulation of the pancreatic gland may cause pancreatic vacuolization. Since then, different models of pancreatitis were described. Up to now, six different models of acute pancreatitis were reported: immunological, secretagogue, induced by diet, ductal interruption and microvascular and ductal injection. The immunological technique uses rabbit serum intraperitoneal and intraductal in rats ${ }^{20}$, leading to severe acute pancreatitis by complement mediated reaction. This model is less used nowadays due to the difficulty to control immune response. It is recommended usually to study toxin or drug induced pancreatitis. The secretagogue-induced acute pancreatitis model needs subcutaneous injection of endovenous drugs that increase the activity of proteolytic enzymes, causing acinar autodigestion. Cerulein is the most widely used substance, characterized by alteration of pulmonary microvascular permeability, leading to lung injury. Thus, this model is suitable to study lung injury following necrotizing acute pancreatitis ${ }^{7,21,22}$. Diet

TABLE 5 - Interlobular septum size comparison between groups

\begin{tabular}{lccc}
\hline Variable & \multicolumn{2}{c}{ Groups compared } & $\boldsymbol{p}$ \\
\hline Size of interlobular septum & S1 & S2 & 0,989 \\
& S1 & A & 0,813 \\
S1 & B & 0,261 \\
S1 & C & $0,035^{*}$ \\
S2 & A & 0,982 \\
S2 & B & 0,541 \\
S2 & C & 0,102 \\
A & B & 0,727 \\
A & C & 0,116 \\
B & C & 0,679 \\
\hline
\end{tabular}
induced pancreatitis with choline-deficient diet supplemented with ethionine depends on gender (just work on female murines) and on the animal's weight (amount of diet uptake). It may provoke liver and central neural system disease and is a major cause of early death ${ }^{14}$. The biliopancreatic ligation proved to cause acute pancreatitis in some studies ${ }^{23}$. However, other researches revealed only pancreatic tissue atrophy ${ }^{24}$. It may be a suitable model to investigate biliary pancreatitis. Microvascular pancreatitis is provoked after the injection 
of polystyrene micro sphere in pancreatic artery lumen ${ }^{25}$. This technique may also lead to an active chronic type of pancreatitis, more useful to the model. The intraductal injection of a variety of drugs is a frequently used technique to develop necrotizing acute pancreatitis. The animals undergo laparotomy, have the pancreatic duct catheterized and the drug is injected simulating biliary reflux. This procedure is doable, but requires practice as it needs accurate movements. The learning curve takes some effort, being this model useful fro gallstones pancreatitis study. The rabbit is a medium size animal, making it possible to take larger blood volume for tests, allowing biochemical evaluation as well as inflammatory cytokines dosage simultaneously ${ }^{11}$. Furthermore, it has been demonstrated that the rabbit's protein are genetically more similar to the human protein, when compared to other ruminants ${ }^{27}$. Hemodynamic monitorization is feasible in the rabbit and more parameters can be evaluated. As expected, serum amylase was elevated, confirming the diagnosis of acute pancreatitis in all animals. In S1 group, where only catheterization of the pancreatic duct was realized, the amylase increase was lower than group S2, where saline infusion was injected. Although not significantly different, it is possible to notice that "the lower the trauma, the lower the amylase levels" was not a rule. These findings indicate that amylase levels were not an indication of the severity of the pancreatitis. Some authors do believe that in spite of being useful for diagnosis, amylase levels do not predict the degree of inflammation ${ }^{3}$. Cellular edema is one of the earliest manifestations of cell injury. The taurocholate injures the pancreatic duct integrity, provoking bile salt leakage and thus, increasing osmotic pressure in the interstice. In our model, the size of interlobular septum rose progressively. Interstitial infiltrate is characterized by the presence of leukocytes and neutrophils, chemoattracted to ischemic areas leading to the rupture of tissue cells. In this study, mild infiltrate was found in groups $\mathrm{S} 1$, $\mathrm{S} 2, \mathrm{~A}$ and $\mathrm{B}$, while in group $\mathrm{C}$ we found severe infiltrate. Steatonecrosis, typical acute pancreatitis injury, was not observed in groups S1 and A and was progressively higher in groups B and C, respectively. Animals in group S1 and S2 did not present parenchyma necrosis. A mild focal necrosis was seen in all animals from group A. Animals from group B developed from focal mild to moderate diffuse pancreatic necrosis, more intense than in group A. Moreover, animals in group $\mathrm{C}$ had severe necrosis on histological evaluation. It was also observed that the degree of necrosis was higher the longer after the taurocholate injection the animal was evaluated. Thus, the necrosis got worse close to the euthanasia moment. Despite the small number of animals, this model proved to be a reproducible model of necrotizing acute pancreatitis, in which severity can be modulated according to the interval between retrograde injection and euthanasia, with no early mortality and morphologically similar to acute onset of pancreatitis in humans. This experimental model may be suitable for studies that evaluate drug concentration and penetration, for the treatment of acute pancreatitis, such as antibiotics. It is also possible to study severity markers, cytokines response and also distant injuries due to the inflammatory process, helping therefore, to find better results in clinical practice of this tricky disease.

\section{References}

1. Bradley EL III. A clinically based classification system for acute pancreatitis. Arch Surg. 1993;128:586-90.

2. Banks PA. Practice guidelines in acute pancreatitis. Am J Gastroenterol. 1997;92(3):377-86.

3. Balthazar EJ. Acute pancreatitis: assessment of severity with clinical and CT evaluation. Radiology. 2002;223:603-13.

4. Sakorafas GH, Tsiotou AG: Etiology and pathogenesis of acute pancreatitis. J Clin Gastroenterol. 2000;30(4):343-56.

5. Steinberg W, Tenner S. Acute pancreatitis. N Engl J Med. 1994;330:1198-210.

6. Halangk W, Lerch MM. Early events in acute pancreatitis. Gastroenterol Clin N Am. 2004;33:717-31.

7. Schmidt J, Rattner D, Lewandrowski K, Compton C, Mandavilli $U$ et al. A better model of acute pancreatitis for evaluate therapy. Ann Surg. 1992;215:44-56.

8. Lerch MM. Do experimental models have clinical relevance? Gastroenterology Week Freiburg (part II). Falk Symposium No 143 Freiburg, Germany, October 14-15, 2004. Available from URL: http://www.pancreasweb.com

9. Nakae Y, Satoru N, Motoji K, Shigeaki H, Ryohei Y, Tetsuo H. Activation of Trypsinogen in experimental models of acute pancreatitis in rats. Pancreas. 1995;10(3):306-12.

10. Osman M, Kristensen J, Jacobsen N, Lausten S, Deleuran M, Gesser B, Matsushima K, Larsen C, Jensen S. A monoclonal anti-interleukin 8 antibody (WS-4) inhibits cytokine response and acute lung injury in experimental severe acute necrotizing pancreatitis in rabbits. Gut. 1998;43:232-9.

11. Osman MO, Gesser B, Mortensen JT, Matsushima K, Jensen SL, Larsen CG. Profiles of pro-inflammatory cytokines in the serum of rabbits after experimentally induced acute pancreatitis. Cytokine. 2002;17:53-9.

12. Ottesen LH, Bladbjerg EM, Osman M, Lausten SB, Jacobsen NO, Gram J, Jensen SL. Protein C activation during the initial phase of experimental acute pancreatitis in the rabbit. Dig Surg. 1999;16(6):486-95.

13. Czako L, Hegyi P, Takacs T, Gog C, Farkas A, Mandy Y, Vargas IS, Tiszlavicz L, Lonovics J. Effects of octreotide on acute necrotizing pancreatitis in rabbits. World J Gastroenterol. 2004;10(14):2082-6. 
14. Gonçalez Y, Machado M, Silva S, Bettarello A. Protective effect of a protein-free diet in acute experimental pancreatitis. Braz J Med Biol Res. 1989;22:477-83.

15. Abdo EE, Gonçalez Y, Machado MC, Aguirre-Costa PL, Gonçalez F, Sampietri SN, Pinotti HW. Mononuclear phagocytic system in acute pancreatitis. Braz J Med Biol Res. 1993;26(3):285-90.

16. de Souza LJ, Sampietre SN, Assis RS, Knowles CH, Leite KR, Jancar S, Monteiro Cunha JE, Machado MC. Effect of platelet-activating factor antagonists (BN-52021, WEB-2170, and BB-882) on bacterial translocation in acute pancreatitis. J Gastrointest Surg. 2001;5(4):364-70.

17. Salem MZ, Cunha JE, Coelho AM, Sampietri SN, Machado MC, Penteado S, Abdo EE. Effects of octreotide pretreatment in experimental acute pancreatitis. Pancreatology. 2003;3(2):164-8.

18. Machado MC, Coelho AM, Pontieri V, Sampietri SN, Molan NA, Soriano F, Matheus AS, Patzina RA, Cunha JE, Velasco IT. Local and systemic effects of hypertonic solution ( $\mathrm{NaCl} 7,5 \%)$ in experimental acute pancreatitis. Pancreas. 2006;32(1):80-6.

19. Banerjee A.K., Galloway S.W., Kingsnorth A.N. Experimental models of acute pancreatitis. Br J Surg. 1994;81:1096-103.

20. Nevalainen T.J. Pancreatic injury caused by intraductal injection of foreign serum in the rat. Virchows Arch B Cell Pathol. 1978;27:89-98.
21. Bieger W, Martin-Achard A, Bassler M, Kern HF. Studies on intracellular transport of secretory proteins in the rat exocrine pancreas. IV Stimulation by in vivo infusion of caerulein. Cell Tissue Res. 1976;165:435-53.

22. Nakae Y, Satoru N, Motoji K, Shigeaki H, Ryohei Y, Tetsuo H. Activation of Trypsinogen in experimental models of acute pancreatitis in rats. Pancreas. 1995;10(3):306-12.

23. Lerch MM, Saluja AK, Runzi M, Dawra R, Saluja M, Steer ML. Pancreatic duct obstruction triggers acute necrotizing pancreatitis in the opossum. Gastroenterology. 1993;104:853-61.

24. Morita Y, Takiguchi M, Yasuda J, Eom K, Hashimoto A. Endoscopic ultrasonographic findings of the pancreas after pancreatic duct ligation in the dog. Vet .Radiol Ultrasound. 1998;39(6):557-62.

25. Redha F, Uhlschmid G, Ammann RW, Freiburghaus AU. Injection of microspheres into pancreatic arteries causes acute haemorrhagic pancreatitis in the rat: a new animal model. Pancreas. 1990;5:188-93.

26. Freiburghaus AU, Redha F, Ammann RW. Acute pancreatitis after microembolism of the rat pancreas progresses into chronic pancreatitis. Digestion. 1993;54:277.

27. Graur D, Duret L, Gouy M. Phylogenetic position of the order Lagomorpha (rabbits, hares and allies). Nature.1996;379:333-5.

\section{Correspondence:}

Alberto Goldenberg

Av. Albert Einstein, 627/1211

05651-901 São Paulo - SP Brazil

goldenb@terra.com.br
Conflict of interest: none Financial source: none

Received: March 14, 2007

Review: May 15, 2007

Accepted: June 12, 2007

\section{How to cite this article}

Goldenberg A, Romeo ACDCB, Moreira MB, Apodaca FR, Linhares MM, Matone J. Experimental model of severe acute pancreatitisinrabbits.ActaCirBras.[serialontheInternet]2007Sept-Oct;22(5).AvailablefromURL: $\underline{\text { htp://www.scielo.br/acb }}$ 